\title{
Laju Pengurangan Kadar Air Pada Lemari Pengering Baju Dengan Memanfaatkan Panas AC
}

\author{
Sumanto ${ }^{1}$, S. Achmadi ${ }^{2}$ \\ ${ }^{*}$ ', Prodi Teknik Industri S1, FTI, ITN Malang \\ ${ }^{2}$ Prodi Teknik Informatika S1, FTI, ITN Malang \\ Email:sumanto@lecturer.itn.ac.id
}

\begin{abstract}
Matahari sebagai sumber energi sangat bermanfaat bagi kehidupan manusia. Salah satu manfaat sinar matahari adalah untuk mengeringkan pakaian setelah dicuci. Ketika musim hujan tiba, masalah yang dihadapi oleh ibu rumah tangga atau pelaku usaha laundry adalah pakaian yang dicuci tidak kering dalam waktu yang singkat. Untuk mengatasi hal tersebut perlu inovasi baru yang dapat membantu proses pengeringan pakaian setelah dicuci. Inovasi ini adalah proses pengeringan baju dengan memanfaatkan sumber panas yang berasal dari kalor pembuangan dari air conditioner (AC) yang sedang beroperasi. Baju setengah kering dimasukkan ke dalam lemari pengering baju. Kalor yang dibuang dari kondensor (condenser) AC disalurkan ke dalam lemari, sehingga suhu dalamnya meningkat dan digunakan untuk mengeringkan pakaian yang telah dicuci. Hasil penelitian menunjukkan bahwa laju pengurangan kadar air untuk dinding lemari dari isolator panas (aluminium foil) adalah $0,10 \mathrm{~kg} / \mathrm{jam}$, untuk dinding GRC $0,05 \mathrm{~kg} / \mathrm{jam}$ dan untuk dinding triplek hanya $0,06 \mathrm{~kg} / \mathrm{jam}$. Dengan hasil ini, kalor buang AC cukup efektif untuk mengeringkan pakaian dalam lemarin pengering yang dindingnya dilapisi isolator panas yang terbuat dari aluminium foil.
\end{abstract}

Keywords kalor, $A C$, pengering, pakaian

Paper type Research paper

\section{Pendahuluan}

Matahari adalah sumber energi utama di bumi ini, sehingga semua energy yang ada sangat bergantung pada panas matahari. Ketika panas matahari dalam hal ini sinar matahari tidak sampai ke bumi, maka system energy yang ada di bumi ini akan terganggu.Permasalahan yang dihadapi oleh pelaku usaha laundry adalah ketika sinar matahari tidak sampai ke bumi. Hal ini terjadi pada musim penghujan atau pada malam hari. Dampak dari kasus ini adalah pakaian yang dicuci tidak dapat kering dengan cepat, sehingga keuntungan dari usaha laundry tidak bias optimal.

Mengatasi keuntungan laundry yang tidak optimal akibat tidak dapat keringnya cucian dengan cepat perlu disikapi dengan inovasi teknologi yang lebih baik. Inti dari permasalahan ini adalah bagaimana merancang sebuah alat yang dapat membantu mengeringkan cucian dengan cepat. Banyak cara yang dapat dilakukan untuk membantu pengeringan cucian, misalnya dengan menseterika pakaian setengah basah, memanaskan cucian di dekat lampu pijar dengan daya yang besar ataua dengan mengeringkan pakaian yang dicuci dengan hair dryer dan lain sebagainya. Usaha-usaha tersebut dapat dilakukan tetapi tidak efektif. Akan lebih baik jika sumber energy panas yang digunakan untuk mengeringkan cucian adalah energy yang berasal dari energy yang terbuang atau dari sumber enrgi terbarukan (misalnya bio masa). Pada penelitian ini akan dirancang sebuah alat pengering pakaian yang menggunakan energy panas yang terbuang yaitu panas dari air conditioner (AC), karena energy panas ini selalu terbuang. Tujuan dari penelitian ini adalah untuk mengetahui laju pengeringan dengan sumber panas dari buangan $\mathrm{AC}$.

\section{AIR CONDITIONER}

AC merupakan suatu instrumen yang digunakan untuk mengontrol temperature udara terutama di dalam ruangan. Ada dua jenis AC, yaitu AC portable yang dapat dipindah-pindahkan dan AC permanen yang tidak dapat dipindahkan. Sedangkan menurut susunan komponen-komponenya AC dibagi menjadi dua yaitu Window AC dan Split AC. AC Window adalah AC yang evaporator dan kondensornya terletak pada 1 buah mesin (dalam bentuk satu alat), sedangkan AC split adalah AC yang evaporator dan kondensor berada dalam dua mesin yang berbeda. Evaporatornya terletak di dalam ruangan. Sedangkan kondensornya terletak di luar ruangan. 
Cara kerja AC dijelaskan sebagai berikut:

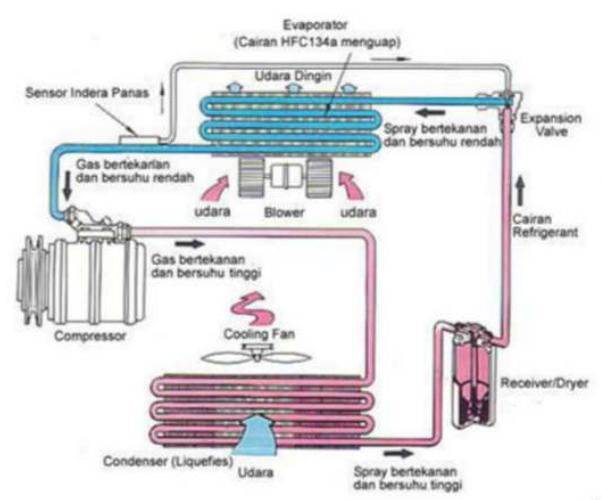

Fig. 1. Gambar Komponen-komponen AC

Kompresor yang ada pada sistem pendingin dipergunakan sebagai alat untuk memampatkan fluida kerja (refrigerant), jadi refrigerant yang masuk ke dalam kompresor dialirkan ke condenser yang kemudian dimampatkan di kondenser. Di bagian kondenser ini refrigerant yang dimampatkan akan berubah fase dari refrigerant fase uap menjadi refrigerant fase cair, maka refrigerant mengeluarkan kalor yaitu kalor penguapan yang terkandung di dalam refrigerant. Adapun besarnya kalor yang dilepaskan oleh kondenser adalah jumlah dari energi kompresor yang diperlukan dan energi kalor yang diambil evaparator dari substansi yang akan didinginkan.

Pada kondensor tekanan refrigerant yang berada dalam pipa-pipa kondenser relatif jauh lebih tinggi dibandingkan dengan tekanan refrigerant yang berada pada pipi- pipa evaporator. Setelah refrigerant lewat kondenser dan melepaskan kalor penguapan dari fase uap ke fase cair maka refrigerant dilewatkan melalui katup ekspansi, pada katup ekspansi ini refrigerant tekanannya diturunkan sehingga refrigerant berubah kondisi dari fase cair ke fase uap yang kemudian dialirkan ke evaporator, di dalam evaporator ini refrigerant akan berubah keadaannya dari fase cair ke fase uap, perubahan fase ini disebabkan karena tekanan refrigerant dibuat sedemikian rupa sehingga refrigerant setelah melewati katup ekspansi dan melalui evaporator tekanannya menjadi sangat turun.

Hal ini secara praktis dapat dilakukan dengan jalan diameter pipa yang ada dievaporator relatif lebih besar jika dibandingkan dengan diameter pipa yang ada pada kondenser. Dengan adanya perubahan kondisi refrigerant dari fase cair ke fase uap maka untuk merubahnya dari fase cair ke refrigerant fase uap maka proses ini membutuhkan energi yaitu energi penguapan, dalam hal ini energi yang dipergunakan adalah energi yang berada di dalam substansi yang akan didinginkan.

Dengan diambilnya energi yang diambil dalam substansi yang akan didinginkan maka enthalpi substansi yang akan didinginkan akan menjadi turun, dengan turunnya enthalpi maka temperatur dari substansi yang akan didinginkan akan menjadi turun. Proses ini akan berubah terus-menerus sampai terjadi pendinginan yang sesuai dengan keinginan. Berdasarkan hukum kedua termodinamika, secara garis besar prinsip kerja AC dijelaskan sebagai berikut:

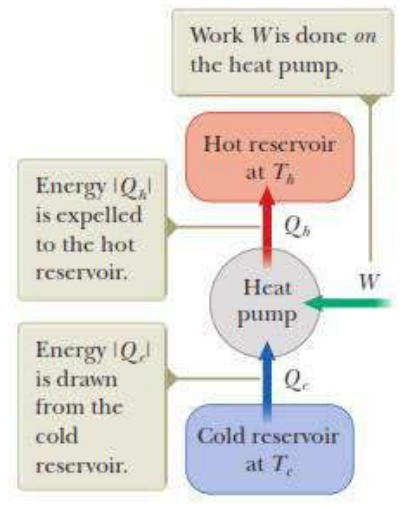

Fig. 2. Gambar Skema representasi air conditioner/heat pump

Secara umum kalor mengalir dari reservoir suhu tinggi ke suhu rendah. Kalor diambil pada reservoir suhu rendah dan dibuang pada reservoir suhu tinggi. Pada kasus heat pump atau AC kalor dipindahkan dari suhu rendah ke suhu tinggi dibantu kerja dari luar. Kerja dari luar disupply oleh energy listrik. Tempat di mana reservoir suhu rendah berada akan menjadi dingin karena kalornya dipindahkan, sedangkan tempat di mana reservoir suhu tinggi berada menjadi panas karena kalor dari reservoir suhu rendah dilepaskan di tempat ini. 


\section{Proses Pengeringan Pakaian}

Proses pengeringan pakaian yang selesai dicuci pada dasarnya adalah proses penguapan. Air yang ada pada pakaian basah diberi kalor, maka akan terjadi kenaikan temperature yang dalam waktu tertentu air berubah menjadi gas sehingga terjadi penguapan yang menyebabkan air lepas dari pakaian. Hasilnya adalah pakaian menjadi kering. Menurut teori kinetik, suhu adalah ekspresi energi rata-rata dari gerak molekul.

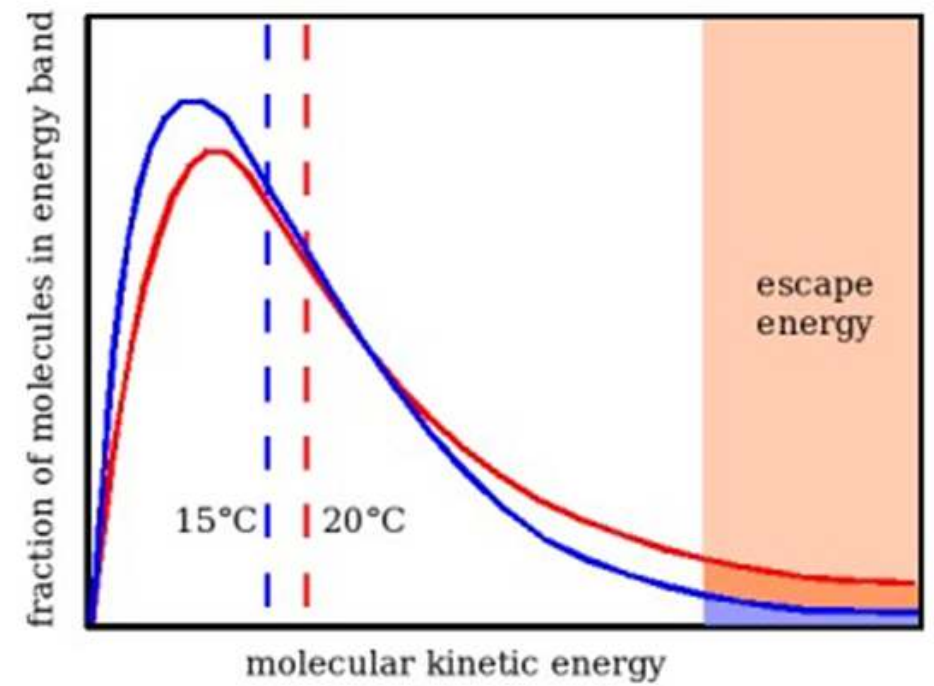

Fig. 3. Gambar Distribusi energi molekul air pada $15^{\circ} \mathrm{C}$ dan $20^{\circ} \mathrm{C}$

Kurva merah pada Gambar 3. menunjukkan secara skematis distribusi energi molekul air pada $20^{\circ} \mathrm{C}$. Hanya molekul dengan energi kinetik tinggi, menuju ujung kanan grafik, yang akan lolos dari permukaan air cair, melawan gaya kohesif yang mengikat molekul-molekul dalam air cair. Segera setelah ini terjadi, molekul yang tersisa mendistribusikan kembali energinya dengan tumbukan, bergerak ke arah kurva biru, mewakili suhu yang lebih rendah, karena energi molekul ratarata lebih rendah (ditunjukkan oleh garis biru putus-putus vertikal).

\section{Metode Penelitian}

Dalam penelitian ini, baju setengah kering dimasukkan ke dalam lemari. Panas berasal dari pebuangan kalor pada AC dimasukkan ke dalam lemari tersebut. Suhu di dalam lemari akan meningkat dan dimanfaatkan untuk mengeringkan baju yang ada di dalamnya. AC yang digunakan adalah AC portable dengan suhu yang dihasilkan dijaga konstan. Pakaian yang telah dicuci dikeringkan dengan pengering mesin cuci, ditimbang dan dikeringkan dalam lemari dan dilakukan proses pengeringan. Setelah waktu tertentu baju diambil dari lemari dan ditimbang lagi untuk mengetahui massa pengurangan massa air dalam pakaian. Pada proses pengeringan ini waktu yang diperlukan untuk pengeringan pakaian diobservasi. Waktu inilah yang akan digunakan untuk menghitung laju pengeringan.

\section{Analisis Data}

Data hasil penelitian ini dianalisis laju pengeringan dengan perhitungan matematika sederhana dengan rumus:

Laju Pengurangan Air $=\frac{m_{i}-m_{f}}{\Delta t}$

$\mathrm{m}_{\mathrm{i}}=$ massa awal

$\mathrm{m}_{\mathrm{f}}=$ massa akhir

$\Delta t=$ selang waktu

Hasil yang diperoleh antara laju pengeringan dari lemari pengering pakaian dibandingkan antara lemari/kabinet berdinding aluminium, GRC dan triplek. 


\section{HASIL DAN PEMBAHASAN}

Hasil penelitian ini disajikan dalam tabel berikut ini:

\begin{tabular}{|c|c|c|c|}
\hline \multirow{2}{*}{ Dinding } & \multirow{2}{*}{ Bahan } & \multicolumn{2}{|c|}{ Massa (gram) } \\
\hline & & Awal & Akhir \\
\hline \multirow{4}{*}{$\begin{array}{l}\text { Papan } \\
\text { (Tripleks) }\end{array}$} & Handuk & 383 & 354 \\
\hline & Baju & 175.5 & 148.3 \\
\hline & $\begin{array}{l}\text { Kaos } \\
\text { Tipis }\end{array}$ & 224.6 & 189 \\
\hline & $\begin{array}{l}\text { Kaos } \\
\text { Tebal }\end{array}$ & 308.4 & 272.5 \\
\hline \multirow{4}{*}{ GRC } & Handuk & 353.8 & 325 \\
\hline & Baju & 147.4 & 141.1 \\
\hline & $\begin{array}{l}\text { Kaos } \\
\text { Tipis }\end{array}$ & 188.2 & 178.4 \\
\hline & $\begin{array}{l}\text { Kaos } \\
\text { Tebal }\end{array}$ & 272.1 & 260.2 \\
\hline \multirow{4}{*}{$\begin{array}{l}\text { Isolator } \\
\text { Panas } \\
\text { (Aluminium } \\
\text { Foil) }\end{array}$} & Handuk & 374.4 & 357 \\
\hline & Baju & 187.1 & 162.9 \\
\hline & $\begin{array}{l}\text { Kaos } \\
\text { Tipis }\end{array}$ & 321.5 & 308.9 \\
\hline & $\begin{array}{l}\text { Kaos } \\
\text { Tebal }\end{array}$ & 231.6 & 216.3 \\
\hline
\end{tabular}

\section{ANALisis Data}

Hasil penelitian dapat dinyatakan sebagai grafik sebagai berikut:

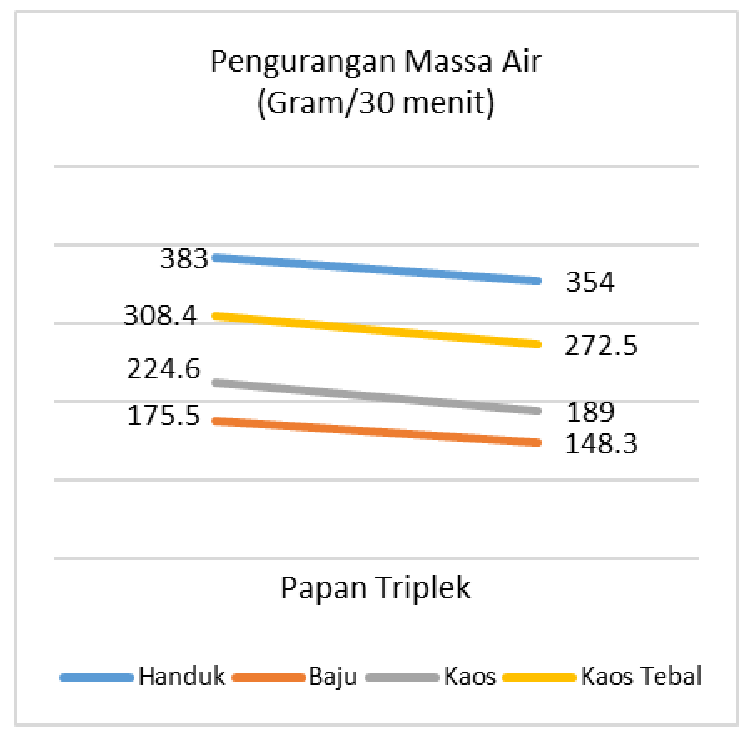

Fig. 4. Gambar Grafik pengurangan massa air dalam interval waktu 30 menit bahan dinding triplek 


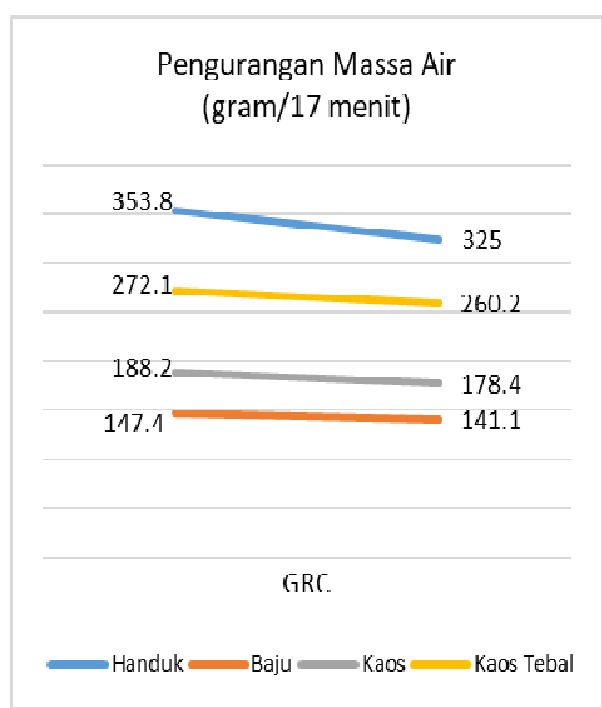

Fig. 5. Gambar Grafik pengurangan massa air dalam interval waktu 17 menit bahan dinding GRC

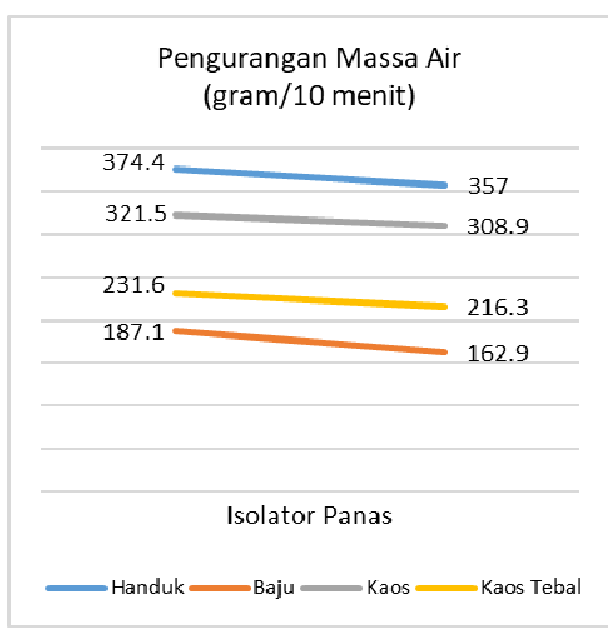

Fig. 6. Gambar Grafik pengurangan massa air dalam interval waktu 10 menit bahan dinding isolator panas

Analisis data penelitian untuk menentukan laju pengeringan disajikan sebagai berikut:

Laju Pengurangan Air $=\frac{m_{i}-m_{f}}{\Delta t}$

Hasil perhitungan laju pengurangan kadar air disajikan dalam table berikut:

\begin{tabular}{lll}
\hline \multicolumn{1}{c}{ Dinding } & $\begin{array}{c}\text { Laju } \\
\text { Pengurangan } \\
\text { Kadar Air } \\
\text { (gr/menit) }\end{array}$ & $\begin{array}{c}\text { Rata-rata } \\
\text { (gr/menit) }\end{array}$ \\
\hline & 0.97 & \\
Papan (Tripleks) & 0.91 & 1.07 \\
& 1.19 & \\
& 1.2 & \\
GRC & 1.69 & 0.84 \\
& 0.37 & \\
\hline Isolator Panas & 0.58 & \\
(Aluminium & 0.7 & \\
Foil) & 2.42 & \\
\hline
\end{tabular}


1. Dinding Papan Triplek

Rata-rata pengurangan kadar air pada pakaian yang dikeringkan dalam lemari pengering berdinding triplek adalah $1.07 \mathrm{gram} / \mathrm{menit}$ atau setara dengan $0.06 \mathrm{~kg} / \mathrm{jam}$.

2. Dinding GRC

Rata-rata pengurangan kadar air pada pakaian yang dikeringkan dalam lemari pengering berdinding GRC adalah $0.84 \mathrm{gram} / \mathrm{menit}$ atau setara dengan $0.05 \mathrm{~kg} / \mathrm{jam}$.

3. Dinding Triplek

Rata-rata pengurangan kadar air pada pakaian yang dikeringkan dalam lemari pengering berdinding isolator panas adalah 1.74 gram $/$ menit atau setara dengan $0.10 \mathrm{~kg} / \mathrm{jam}$.

\section{Pembahasan}

Pemanfaatan panas buangan dari AC untuk mengeringkan pakaian dapat digunakan secara efektif, terutama pada kondisi sinar matahari tidak banyak membantu proses pengeringan (cuaca mendung). Dari hasil penelitian diperoleh bahwa pada suhu AC $17{ }^{\circ} \mathrm{C}$ laju pengurangan kadar air terbesar pada bahan dinding lemari pengering isolator panas dalam hal ini adalah aluminium foil.

Pada dinding lemari pengering yang terbuat triplek dan GRC penyerapan panas oleh dinding cukup besar sehingga panas yang dimanfaatkan untuk pengeringan pakaian berkurang. Sedangkan pada dinding yang dilapisi isolator panas, panas yang terserap dinding cukup sedikit sehingga pemanfataan panas AC untuk mengeringkan pakaian lebih efektif.

Penggunaan lemari penering pakaian ini cukup efektif dalam membantu proses pengeringan pakaian yang selesai dicuci di musin penghujan atau cuaca mendung. Karena penggunaan panas buangan AC cukup efektif untuk meneringkan baju, maka teknologi ini dapat dimanfaatkan oleh pelaku usaha laundry untuk membantu mengeringkan pakaian yang basah pada musim penghujan. Lebih-lebih teknologi ini hanya memanfaatkan energi kalor yang seharusnya terbuang secara percuma.

\section{KESIMPULAN DAN SARAN}

Pemanfatan kalor pembuangan dari kondensor AC mampu mengeringkan pakaian dengan laju 0,10kg/jam untuk dinding pengering dari isolator panas (aluminium foil), $0,05 \mathrm{~kg} / \mathrm{jam}$ untuk dinding pengering dari GRC dan 0,06 untuk dinding pengering dari triplek. Dengan hasil ini maka teknologi ini dapat digunakan oleh ibu-ibu rumah tangga dan pelaku usaha laundry untuk membantu mempercepat pengeringan pakaian yang telah dicuci pada musim penghujan atau cuaca mendung.

\section{REFERENCES}

[1] Ambarita Himsar dkk. 2016. Performance Of A Clothes Drying Cabinet By Utilizing Waste Heat From A Split-Type Residential Air Conditioner. 2214-157X/\& 2016 The Authors. Published by Elsevier Ltd

[2] Karyoto. AC Window dan AC Split. http://staffnew.uny.ac.id/upload/132100514/pendidikan/materi-kuliah-ac-window-dan-split- hto.pdf

[3] Serway \& Jewett. 2014. Physics for Scientists and Engineers With Modern Physics. $9^{\text {th }}$ Edition. Brooks/Cole Cengage Learning.

[4] Shan K. Wang. 2001. Handbook Of Air Conditioning And Refrigeration. 2nd Edition. McGraw-Hill

[5] Tim ASTRO 7. Cara Kerja Sistem AC Ruangan. https://cvastro.com/cara- kerja-sistem-ac-ruangan.htm

[6] Varman, Mahendra dkk. 2010. Clothes Drying From Room Air Conditioning Waste Heat: Thermodynamics Investigation. The Arabian Journal for Science and Engineering, Volume 35, Number 1B. 